\title{
RESISTANCE OF Echinochloa crusgalli var. mitis TO IMAZAPYR+IMAZAPIC HERBICIDE AND ALTERNATIVE CONTROL IN IRRIGATED RICE
}

BONOW, J.F.L. ${ }^{1}$

LAMEGO, F.P. ${ }^{2 *}$

ANDRES, A. ${ }^{3}$

AVILA, L.A. ${ }^{1}$

TELÓ, G.M. ${ }^{4}$

EGEWARTH, K. ${ }^{1}$

\section{* Corresponding author:}

<fabiane.lamego@embrapa.br>

Received: September 5, 2016

Approved: December 31, 2016

\section{Planta Daninha 2017; v35:e017168627}

Copyright: This is an open-access article distributed under the terms of the Creative Commons Attribution License, which permits unrestricted use, distribution, and reproduction in any medium, provided that the original author and source are credited.

\section{Resistência de Echinochloa crusgalli var. mitis ao Herbicida \\ Imazapyr+Imazapic e Controle Alternativo em Arroz Irrigado}

ABSTRACT - The introduction of Clearfield ${ }^{\circledR}$ system for irrigated rice production provided an effective management strategy in the selective control of weeds. However, the selection pressure caused by the continuous use of herbicides such as imazapyr+imazapic belonging to the imidazolinone chemical group, without the proper integrated management of weeds, has favored the selection of resistant accessions. The goals of this work were to confirm the resistance to ALS inhibitors in accessions of E. crusgalli var. mitis collected in rice fields of the state of Rio Grande do Sul and to evaluate the control with alternative herbicides registered for weed control. Three experiments were conducted in a greenhouse using plant seeds that survived the application of the herbicide imazapyr+imazapic, collected in irrigated rice producing regions with suspected resistance escapes. For dose-response curve study, three resistant accessions (ECH1 - Pelotas/Rio Grande do Sul, ECH27 - Arroio Grande/Rio Grande do Sul and ECH38 - Rio Grande/Rio Grande do Sul) and two susceptible accessions (ECH14 - Pelotas/Rio Grande do Sul and ECH44 - Rio Grande / Rio Grande do Sul) (factor A) and 11 doses of the herbicide imazapyr+imazapic (factor B) were selected. The results indicate that barnyardgrass resistant accessions present a high resistance level to imazapyr+imazapic. ALS inhibiting herbicides such as imazethapyr+imazapic, bispyribac-sodium and penoxsulam did not control the resistant accessions either. Integrated weed management should be adopted and alternative mechanisms of action as ACCAse (cyhalofop-butyl, profoxydim and clethodim) and EPSPS (glyphosate) inhibitors are still eficients controlling barnyardgrass ALS resistant accessions.

Keywords: barnyardgrass, herbicide, alternative chemical control, ALS-inhibiting resistance.

RESUMO - A introdução do sistema Clearfield ${ }^{\circledR}$ de produção de arroz irrigado proporcionou estratégia eficaz no controle seletivo de plantas daninhas. No entanto, a pressão de seleção causada pelo uso contínuo de herbicidas como imazapyr+imazapic, pertencente ao grupo químico das imidazolinonas, sem o adequado manejo integrado de plantas daninhas, tem favorecido a seleção de acessos de plantas daninhas resistentes. Os objetivos deste trabalho foram confirmar a resistência aos inibidores da ALS em acessos de $\boldsymbol{E}$. crusgalli var. mitis coletados em lavouras do RS e avaliar o controle desses acessos com herbicidas alternativos registrados para o controle da espécie daninha na cultura do arroz irrigado. Foram conduzidos três experimentos em casa de vegetação, utilizando-se sementes provenientes de plantas que sobreviveram à aplicação do herbicida

1 Universidade Federal de Pelotas, Pelotas-RS, Brasil; ${ }^{2}$ Embrapa Pecuária Sul, Bagé-RS, Brasil; ${ }^{3}$ Embrapa Clima Temperado, Pelotas-RS, Brasil; ${ }^{4}$ Louisiana State University, Baton Rouge-LA, EUA. 
imazapyr+imazapic, coletadas em lavouras com escapes suspeitos de resistência, em regiões produtoras de arroz irrigado. Para o estudo de curva de dose-resposta, foram selecionados três biótipos resistentes (ECH1 - Pelotas/RS, ECH27 - Arroio Grande/RS e ECH38 - Rio Grande/RS) e dois suscetiveis (ECH14 - Pelotas/RS e ECH44 - Rio Grande/RS) (fator A) e 11 doses do herbicida imazapyr+imazapic (fator B). $O s$ resultados indicam que os acessos resistentes de capim-arroz apresentam elevado fator de resistência ao imazapyr+imazapic. Os herbicidas inibidores da ALS como imazethapyr+imazapic, bispyribacsodium e penoxsulam, não controlaram os acessos resistentes também. O manejo integrado de plantas daninhas deveria ser adotado e mecanismos de ação alternativos como inibidores da ACCAse (cyhalofopbutyl, profoxydim e clethodim) e da EPSPS (glyphosate) ainda são eficientes em controlar acessos de capim-arroz resistentes a ALS.

Palavras-chave: capim-arroz, herbicida, controle químico alternativo, resistência aos inibidores da ALS.

\section{INTRODUCTION}

Barnyardgrass (Echinochloa spp.) is an important weed in rice cultivation. Its initial management is important and has generally been performed with herbicides inhibiting the acetolactate synthase (ALS) enzyme, which is the main tool to control weeds in different cropping systems (Tranel and Wright, 2002). ALS inhibiting herbicides act on the first enzyme in the synthesis route of the side chain amino acids (valine, leucine and isoleucine), where the blocking of the route affects cell division and the synthesis of DNA, cause the accumulation of ketobutyrate and the blockage of the Acetyl-CoA synthesis (Duggleby et al., 2008).

ALS inhibiting herbicides were introduced on the world market in 1982 and are currently the leading class with cases of resistance in the world, with 63\% of cases (Heap, 2017). Resistant biotypes have the natural and inherited ability to survive and reproduce after the exposure to herbicide rates that would be lethal to susceptible individuals from the same species (Powles and $\mathrm{Yu}, 2010)$. Weed genetic factors can strongly contribute to the emergence of resistance, such as a high initial frequency of the gene responsible for resistance, which is more evident in cases involving ALS inhibiting herbicides (Tranel and Wright, 2002).

Another factor that contributes to the expressive number of species that are resistant to ALS inhibitors is the presence of nuclear dominance and semidominance alleles, which allow rapid dispersion of the resistance, due to the ability of cross-fertilization via pollen (Tranel and Wright, 2002). The predominance of weeds that are resistant to these herbicides in different crops makes this herbicide class the most problematic, mainly in irrigated rice cultivation, due to the continuous use of imazapyr + imazapic, a product of the Clearfield ${ }^{\circledR}$ technology.

Herbicide resistance can be diagnose using dose-response curves (Perez-Jones, 2007), where non-linear regression determine the $\mathrm{C}_{50}$ index, that is, the herbicide dose necessary to control $50 \%$ of the population, allowing the comparison of resistant and susceptible biotypes (Christoffoleti, 2002). Once resistance is confirmed, control measures should be taken to minimize the negative effects of weed accessions. Among the chemical management ways for herbicide-resistant biotypes, there is the use of different mechanisms of action or the association of herbicides with distinct mechanisms of action (Powles and Yu, 2010); they are effective alternatives in controlling resistant weeds, as well as avoiding the selection of new resistant accessions (Oliveira Neto et al., 2010).

This study had the goal to confirm the resistance to ALS inhibitors in accessions of E. crusgalli var. mitis in the state of Rio Grande do Sul, and to evaluate the control of these accessions with alternative herbicides registered for the control of weed species in irrigated rice crops.

\section{MATERIAL AND METHODS}

In the $2013 / 2014$, seeds of barnyardgrass plants that survived the application of imazapyr + imazapic herbicide, were harvested in crops of the southern region of Rio Grande do Sul state. Seeds of 49 accessions were collected in the cities of Rio Grande, Arroio Grande, Pelotas, Santa 
Vitória do Palmar and Capão do Leão; they came from individual plants. After harvested, seeds from each accession were cleaned and stored individually for six months in brown paper bags, at room temperature, until the tests were implanted.

In August 2014, the seeds of suspected resistant accessions were sown in trays in a greenhouse at Embrapa CPACT/ETB, Capão Leão-RS. After their emergence, plants were transplanted to plastic pots, with a volumetric capacity of $0.5 \mathrm{~L}$, containing dystrophic haplic Planosol type soil. Soil analysis presented $\mathrm{pH}$ in water 5.0; $\mathrm{CTC}_{\mathrm{pH} 7}=7.1 \mathrm{cmol}_{\mathrm{c}} \mathrm{dm}^{-3}$; organic matter $=1.8 \%$; clay $=14 \%$; texture $=4 ; \mathrm{Ca}=4.1 \mathrm{cmol}_{\mathrm{c}} \mathrm{dm}^{-3} ; \mathrm{Mg}=1.1 \mathrm{cmol}_{\mathrm{c}} \mathrm{dm}^{-3} ; \mathrm{Al}=1.6 \mathrm{cmol}_{\mathrm{c}} \mathrm{dm}$ ${ }^{3} ; \mathrm{P}=6.5 \mathrm{mg} \mathrm{dm}^{-3}$; and $\mathrm{K}=0.15 \mathrm{cmol}_{\mathrm{c}} \mathrm{dm}^{-3}$. Soil fertilizing correction was performed according to the recommendations for irrigated rice (SOSBAI, 2012).

A screening of the harvested accessions was carried out in a completely randomized design (CRD) study with four replications, with the application of the formulated mixture of imazapyr+imazapic $\left(\mathrm{Kifix}^{\circledR}\right)$, at the maximum registered dose to control barnyardgrass, corresponding to $73.5+24.5$ g e.a. ha ${ }^{-1}$, when they reached the 3-4 leaf stage.

Herbicide application was performed with a $\mathrm{CO}_{2}$ pressurized backpack sprayer, calibrated to provide a spray volume of $140 \mathrm{~L} \mathrm{ha}^{-1}$, equipped with 110.015 fan-type spraying nozzles, spaced $50 \mathrm{~cm}$ apart.

The control evaluation was performed 28 days after the treatment application, adopting a percentage scale where zero (0) and one hundred (100) corresponded to absence of damage and death of plants, respectively (Frans and Crowley, 1986). In this preliminary study, five accessions were selected, three resistant and two susceptible ones. The accessions were then isolated in a greenhouse to avoid cross-pollination, in order to obtain the following generation of seeds as material for subsequent experiments.

Samples from the accessions were sent to the Herbário PEL from Universidade Federal de Pelotas - UFPel and identified as Echinochloa crusgalli var. mitis.

\section{Dose-response curve study}

The determination of the imazapyr+imazapic dose necessary to control $50 \%$ of the population $\left(\mathrm{C}_{50}\right)$ and to reduce $50 \%$ of the dry mass production by barnyardgrass $\left(\mathrm{GR}_{50}\right)$ in susceptible and resistant accessions was performed by a greenhouse study, installed on December 2nd and 3rd 2014, using a CRD with four replications. After their emergence, plants were transplanted to plastic pots with a volumetric capacity of $0.7 \mathrm{~L}$, containing dystrophic haplic Planosol type soil. Seeds from the accessions selected for the studies were sown and, subsequently, seedlings were thinned in order to etablish one plant per pot.

The treatments were arranged in a factorial scheme, where factor A was constituted by the barnyardgrass accessions (ECH1, ECH14, ECH27, ECH38 and ECH44), and factor $\mathrm{B}$ was the herbicide doses (imazapyr + imazapic): $0 ; 0.125 ; 0.25 ; 0.5 ; 1 ; 2 ; 4 ; 8 ; 16 ; 32$; and $64 \mathrm{x}$ the maximum recommended dose of $73.5+24.5 \mathrm{~g}$ a.e. $\mathrm{ha}^{-1}$.

The treatments were applied when the plants reached the 3-4 leaf stage, with a $\mathrm{CO}_{2}$ pressurized backpack sprayer, with 110.015 fan type spraying nozzles, spaced $50 \mathrm{~cm}$ apart, at a constant pressure of $210 \mathrm{KPa}$, adjusted to a spray volume equivalent to $140 \mathrm{~L} \mathrm{ha}^{-1}$.

The evaluated variables were: control on day 14 and 28 after application (DAA) and shoot dry matter (SDM) on day 28 DAA. Control evaluations were performed using the percentage scale adapted from Frans and Crowley (1986). SDM was determined by drying the plant material in an oven at the temperature of $60^{\circ} \mathrm{C}$, until reaching constant mass.

The obtained data were analyzed for their homoscedasticity and were later submitted to analysis of variance $(\mathrm{p} \leq 0.05)$. When statistically significant, data were adjusted to the log-logistic nonlinear regression model using the SigmaPlot 12.0 software (Sigmaplot, 2012), and $\mathrm{C}_{50}$ and $\mathrm{GR}_{50}$ values were calculated from the parameters of the equation (Seefeldt et al., 1995), which relates the response of the plant (control) to the herbicide dose. Values were adjusted to the logistic-type sigmoid regression equation: $\mathrm{y}=\mathrm{a} /\left[1+\left(\mathrm{x} / \mathrm{x}_{0}\right)^{\mathrm{b}}\right]$, where: $\mathrm{y}=$ control percentage; 
$\mathrm{x}=$ herbicide dose; and $a, x_{0}$ and $b=$ equation parameters, where $a$ is the difference between the maximum and minimum points of the curve, $x_{0}$, is the dose providing $50 \%$ of the variable response, and $b$ is the curve gradient.

The resistance factor $(\mathrm{RF})$ was calculated by the ration between C50 or GR50 of the resistant accession and its corresponding susceptible accession.

\section{Alternative chemical control}

An experiment was conducted in a greenhouse, during November and December 2014, using the CRD with six replications. The experimental units were composed of $0.7 \mathrm{~L}$ plastic pots, filled with soil containing one barnyardgrass plant per pot, as described in the previous study. The establishment of the accessions, the application of the treatments, the application stage, the maintenance of the water blade and the methodology used to evaluate each variable were the same described in the dose-response study.

The treatments were defined based on herbicides recommended to weed management, taking into account the selectivity within the crop. Herbicides, and their respective doses, were: imazethapyr + imazapic $\left(56.2+18.7\right.$ g a.e. ha $\left.{ }^{-1}\right)$, imazapyr + imazapic $\left(73.5+24.5\right.$ g a.e. ha $\left.{ }^{-1}\right)$, bispyribac sodium (50 g a.i. ha-1), penoxsulan (57.6 g a.i. ha-1), cyhalofop-butyl (315 g a.i. ha-1), profoxydim (170 g a.i. ha ${ }^{-1}$ ), clethodim (240 g a.i. ha-1), Quinclorac (375 g a.i. ha-1), glyphosate $\left(1,440 \mathrm{~g}\right.$ a.i. $\left.\mathrm{ha}^{-1}\right)$ and propanil $\left(4,000 \mathrm{~g}\right.$ a.i. ha $\left.{ }^{-1}\right)$.

The following adjuvants were used according to the recommendations for each product: Dash ${ }^{\circledR}$ $(0.5 \% \mathrm{v} / \mathrm{v})$ for imazethapyr+imazapic and imazapyr+imazapic; Assist ${ }^{\circledR}(0.5 \% \mathrm{v} / \mathrm{v})$ for clethodim and quinclorac; Assist ${ }^{\circledR}(0.3 \% \mathrm{v} / \mathrm{v})$ for profoxydim; Veget Oil ${ }^{\circledR}\left(3.0 \mathrm{~L} \mathrm{ha}^{-1}\right)$ for cyhalofop-butyl; Veget $\mathrm{Oil}^{\circledR}\left(1.0 \mathrm{~L} \mathrm{ha}^{-1}\right)$ for penoxsulam; and the adhesive spreader $(0.25 \% \mathrm{v} / \mathrm{v})$ for bispyribac-sodium.

The evaluation on plant control was made visually 28 days after the application of the herbicides (DAA), together with the plant collection in order to determine SDM.

The obtained data were analyzed as for their homoscedasticity and were later submitted to analysis of variance $(\mathrm{p} \leq 0.05)$. When statistically significant, the accessions were compared by the t test $(p \leq 0.05)$ and the herbicide treatments by the Duncan test $(p \leq 0.05)$.

\section{RESULTS AND DISCUSSION}

The performed screening showed that $38(78 \%)$ of the 49 accessions collected and analyzed were not controlled by the maximum dose of the used herbicide, based on the percentage scale adapted from Frans and Crowley (1986). The maximum dose was used since, in order to classify a plant as resistant; it should survive and reproduce after the exposure to the labelled rate of the product to control the species, according to the application criteria (vegetative stage indicated, climate conditions, among others) (Gazziero et al., 2009). Thus, plants from the accessions that survived the screening were determined as originated from resistant accessions: accessions ECH1 from Pelotas (latitude 31 30’33" S and longitude 52 $10^{\prime} 45^{\prime \prime} \mathrm{W}$ ), ECH27 from Arroio Grande (latitude 32'18'27" S and longitude 52'52'26" W) and ECH38 from Rio Grande (latitude 32'12’57" S and longitude 52 $30^{\prime} 09^{\prime \prime} \mathrm{W}$ ), as resistant. Plants that not survived as accessions ECH14 (latitude

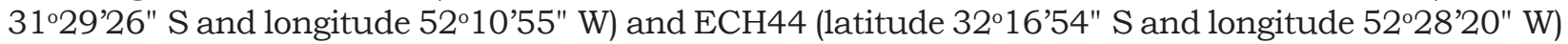
were considered as susceptible, coming from Pelotas and Rio Grande, respectively.

\section{Dose-response curve study}

According to the visual control, there was an interaction $(\mathrm{p} \leq 0.05)$ for accessions and doses (Figure 1), 14 DAA. For the ECH1, ECH14, ECH27 and ECH44 accessions, the sigmoid logistic regression model was the one that fitted data (Table 1), whereas for the ECH38 accession there was no curve adjustment, since $100 \%$ of plant control was not obtained. On day 14 DAA, it was already possible to confirm that the $\mathrm{ECH} 14$ and $\mathrm{ECH} 44$ accessions are susceptible to the herbicide (Figure 1), and that the determination coefficients $\left(R^{2}\right)$ presented values of 0.99 and 0.98 , respectively. $\mathrm{C}_{50}$ was calculated only for two resistant accessions; ECH1 was equivalent to 7.01 


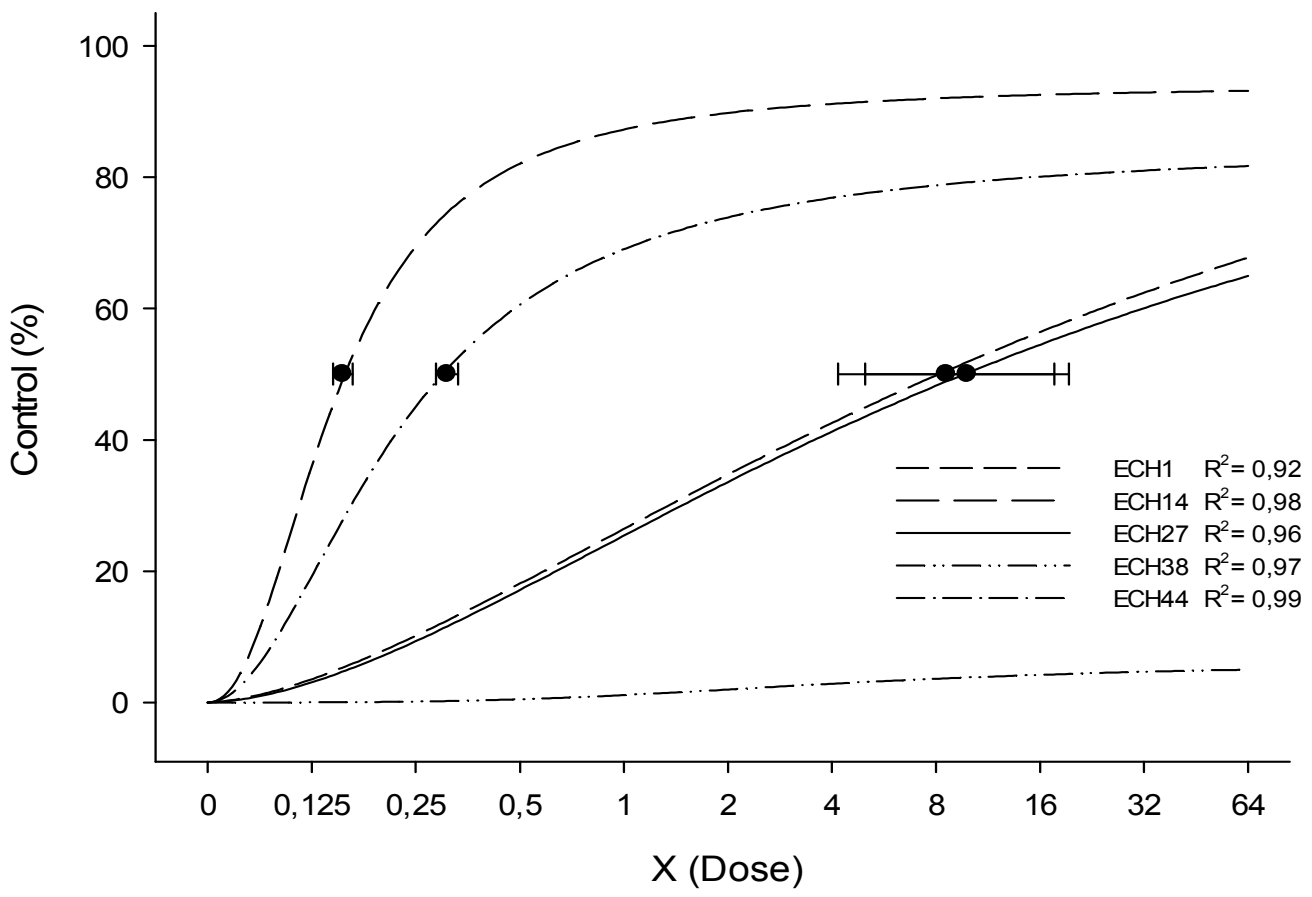

The horizontal bars represent the confidence intervals for the dose causing $50 \%$ control over the plant, with $95 \%$ significance.

Figure 1 - Control (\%) of Echinochloa crusgalli var. mitis (barnyardgrass) accessions resistant (ECH1-Pelotas/Rio Grande do Sul, ECH27-Arroio Grande and ECH38-Rio Grande/Rio Grande do Sul) and susceptible (ECH14-Pelotas/Rio Grande do Sul and ECH44-Rio Grande/Rio Grande do Sul) to imazapyr+imazapic herbicide, evaluated 14 days after the application of the treatment (DAA), according to different doses.

Table 1 - Logistic type sigmoid regression equation to control Echinochloa crusgalli var. mitis (barnyardgrass) accessions on day 14 and 28 after the application of the treatment (DAA) and SDM on day 28 DAA, with the respective $\mathrm{C}_{50}$ values ( $\mathrm{x}$ dose), confidence interval (CI) and resistance factor (RF), in response to the application of imazapyr+imazapic doses

\begin{tabular}{|c|c|c|c|c|c|c|}
\hline \multirow{2}{*}{ Accession } & \multirow{2}{*}{ Equation } & \multirow{2}{*}{$\mathrm{R}^{2}$} & \multicolumn{2}{|c|}{$\left(\mathrm{C}_{50}\right)^{(1)}$ or $\left(\mathrm{GR}_{50}\right)^{(2)}$} & \multicolumn{2}{|c|}{$(\mathrm{RF})^{(4)}$} \\
\hline & & & $\mathrm{X} 0$ & $\mathrm{CI}^{(3)}$ & ECH14 & ECH44 \\
\hline & \multicolumn{6}{|c|}{14 DAA } \\
\hline ECH1 & $\mathrm{y}=105.71 /\left[1+(\mathrm{x} / 9.25)^{-1.59}\right]$ & 0.92 & 9.25 & 2.13 & 74.61 & 25.01 \\
\hline ECH14 & $\mathrm{y}=98.13 /\left[1+(\mathrm{x} / 0.12)^{-2.18}\right]$ & 0.98 & 0.12 & 0.19 & - & - \\
\hline $\mathrm{ECH} 27$ & $\mathrm{y}=101.63 /\left[1+(\mathrm{x} / 8.23)^{-1.69}\right]$ & 0.96 & 8.23 & 1.97 & 66.37 & 22.18 \\
\hline ECH38 & $\mathrm{y}=5.97 /\left[1+(\mathrm{x} / \mathrm{x} 0)^{-3.36}\right]$ & 0.97 & $>64 x$ & - & - & - \\
\hline \multirow[t]{2}{*}{ ECH44 } & $\mathrm{y}=98.41 /\left[1+(\mathrm{x} / 0.37)^{-1.95}\right]$ & 0.99 & 0.37 & 0.21 & - & - \\
\hline & \multicolumn{6}{|c|}{$28 \mathrm{DAA}$} \\
\hline ECH1 & $\mathrm{y}=104.68 /\left[1+(\mathrm{x} / 1.54)^{-1.02}\right]$ & 0.98 & 1.54 & 2.09 & 15.2 & 10.2 \\
\hline ECH14 & $\mathrm{y}=100.14 /\left[1+(\mathrm{x} / 0.10)^{-4.28}\right]$ & 0.99 & 0.10 & 0.05 & - & - \\
\hline $\mathrm{ECH} 27$ & $\mathrm{y}=103.81 /\left[1+(\mathrm{x} / 2.52)^{-1.06}\right]$ & 0.96 & 2.82 & 2.74 & 27.9 & 18.6 \\
\hline ECH38 & $\mathrm{y}=51.31 /\left[1+(\mathrm{x} / \mathrm{x} 0)^{-2.02}\right]$ & 0.96 & $>64 x$ & - & - & - \\
\hline \multirow[t]{2}{*}{ ECH44 } & $\mathrm{y}=103.01 /\left[1+(\mathrm{x} / 0.15)^{-2.49}\right]$ & 0.99 & 0.15 & 0.07 & - & - \\
\hline & \multicolumn{6}{|c|}{ SDM } \\
\hline ECH1 & $\mathrm{y}=98.97 /\left[1+(\mathrm{x} / 1.75)^{2.22}\right]$ & 0.98 & 1.75 & 1.81 & 15.91 & 13.46 \\
\hline ECH14 & $\mathrm{y}=100.01 /\left[1+(\mathrm{x} / 0.11)^{2.86}\right]$ & 0.99 & 0.11 & 0.09 & - & - \\
\hline ECH27 & $\mathrm{y}=98.02 /\left[1+(\mathrm{x} / 7.96)^{1.12}\right]$ & 0.91 & 7.96 & 2.23 & 72.36 & 61.23 \\
\hline ECH38 & $\mathrm{y}=100.99 /\left[1+(\mathrm{x} / \mathrm{x} 0)^{1.28}\right]$ & 0.94 & $>64 x$ & - & - & - \\
\hline ECH44 & $\mathrm{y}=99.84 /\left[1+(\mathrm{x} / 0.13)^{1.33}\right]$ & 0.99 & 0.13 & 0.14 & - & - \\
\hline
\end{tabular}

(1) $\mathrm{C}_{50}=$ necessary dose to control $50 \%$ of the population. (2) $\mathrm{G}_{\mathrm{R} 50}=$ necessary dose to control $50 \%$ of the dry matter. ${ }^{(3)} \mathrm{CI}=$ confidence interval at $95 \%$ parameter error probability. ${ }^{(4)} \mathrm{RF}=$ calculation performed through the ratio between $\mathrm{C}_{50}$ or $\mathrm{GR}_{50}$ of the resistant accession and its correspondent of the susceptible accession. 
and ECH27 was equivalent to 7.27 times the maximum dose for the post-emergence control of barnyardgrass $\left(73.5+24.5 \mathrm{~g}\right.$ a.e. $\left.\mathrm{ha}^{-1}\right)$ (Table 1$)$.

Starting from the established $\mathrm{C}_{50}$ values, it was possible to calculate the $\mathrm{RF}$ for each accession; for ECH1 from Pelotas and ECH27 from Arroio Grande, RF varied from 25.01 and 22.18 (related to ECH44) to 74.61 and 66.37 (related to ECH14), respectively. Depending on the overlapping of the intervals, the resistant accesses ECH1 and ECH27, although coming from different places, show very similar $\mathrm{C}_{50}$ values, whereas ECH38 from Rio Grande presented only 5\% of control when submitted to the application at the maximum recommended dose. Thus it was not possible to calculate $\mathrm{C}_{50}$ for ECH38 access, since it presented only $15 \%$ of control when submitted to the application of up to 64 times the recommended dose. The low control level observed for ECH38, when the ALS inhibiting herbicide was applied demonstrates the high level of resistance presented by the accession.

For control results on day 28 DAA, the sigmoid logistic regression model also fitted the data (Table 1); the use of sub-doses of 0.10 for ECH14 and 0.15 times the register dose for ECH44, respectively, was enough to control $50 \%$ of the population of susceptible accessions (Figure 2). However, in order to obtain the same control percentage in the resistant accessions, it is necessary to use higher doses than the registered one, that is, 1.54 and 2.82 times for the resistant accesses ECH1 and ECH27, respectively.

Using the $\mathrm{C}_{50}$ result obtained for the herbicide imazapyr + imazapic, the RF value was calculated, where it was possible to observe that the ECH1 and ECH27 accessions required 15.2 and 27.9 times, respectively, the dose that controlled $50 \%$ of their populations, in relation to susceptible access ECH14 (Table 1). When compared to the susceptible access ECH44, the RF of the same resistant accessions presented lower values, equivalent to 10.2 and 18.6, respectively. As for the ECH38 accession, it was not possible to calculate the RF, since the control levels for all doses did not reach 50\% control, even when overdoses of the herbicide imazapyr + imazapic were used. Similar results were found for Raphanus sativus plants resistant and susceptible to the ALS inhibiting herbicide (iodosulfuron-methyl sodium), where it was necessary to use 33 and 274 times the dose indicated to reach a satisfactory level of control (80\%), making impossible to use the herbicide to control resistant turnips (Cechin et al., 2016). In order to this control level to be reached for the ECH1 and ECH27 accessions, it is necessary to use 14.2 and 32 times the registered dose to control this species in irrigated rice crops.

In studies conducted with Sagittaria montevidensis under controlled conditions, it was observed that an increase in the imazethapyr + imazapic dose, equivalent to 64 times the recommended dose, did not increase the mortality of the ALS inhibitor-resistant Sagittaria montevidensis, where control did not reach $10 \%$, highlighting the high resistance degree of this population to the ALS inhibiting herbicides. In the same study, the susceptible Sagittaria biotype, when receiving the application of a recommended half dose of imazethapyr + imazapic, demonstrated total control of the plants, highlighting their high susceptibility to these herbicides (Moura et al., 2015). This behavior is similar to the one of the results obtained in this study, where the recommended dose of the herbicide imazapyr + imazapic totally controlled the susceptible accessions, whereas for resistant accessions, there were few or no phytotoxicity symptoms.

Weeds resistant to ALS enzyme inhibiting herbicides tend to present high resistance levels. According to Han et al. (2012), this situation is common, since the mutation in the ALS enzyme may result in high RF and, therefore, in the need of using higher doses than those used to control susceptible plants.

SDM results demonstrate difference between the accessions for the dose that controls $50 \%$ of the population (Figure 3). The highest SDM accumulation was observed for ECH38, which showed a $20 \%$ drop only in the application of very high doses of the herbicide imazapyr + imazapic. However, for ECH1, the dose required to reduce $50 \%$ of the SDM $\left(\mathrm{GR}_{50}\right)$ was 1.75 , and for ECH27 it was 7.96 times the recommended dose. For the susceptible accessions ECH14 and ECH44, the $\mathrm{GR}_{50}$ was needed 0.11 and 0.13 of the recommended rate $73.5+24.5 \mathrm{~g}$ a.e. ha ${ }^{-1}$ (Table 1). With this, it is possible to state that barnyardgrass accessions ECH1, ECH27 and ECH38 from Pelotas, Arroio Grande and Rio Grande, respectively, are resistant to the herbicide imazapyr + imazapic, and the resistant biotype ECH38 shows the higher resistance level. 




The horizontal bars represent the confidence intervals for the dose causing $50 \%$ control over the plant, with $95 \%$ significance.

Figure 2 - Control (\%) of Echinochloa crusgalli var. mitis (barnyardgrass) accessions that are resistant (ECH1-Pelotas/Rio Grande do Sul, ECH27-Arroio Grande and ECH38-Rio Grande/Rio Grande do Sul) and susceptible (ECH14-Pelotas/Rio Grande do Sul and ECH44-Rio Grande/Rio Grande do Sul) to the herbicide imazapyr+imazapic, evaluated on day 28 after the application of the treatment (DAA), according to different doses.

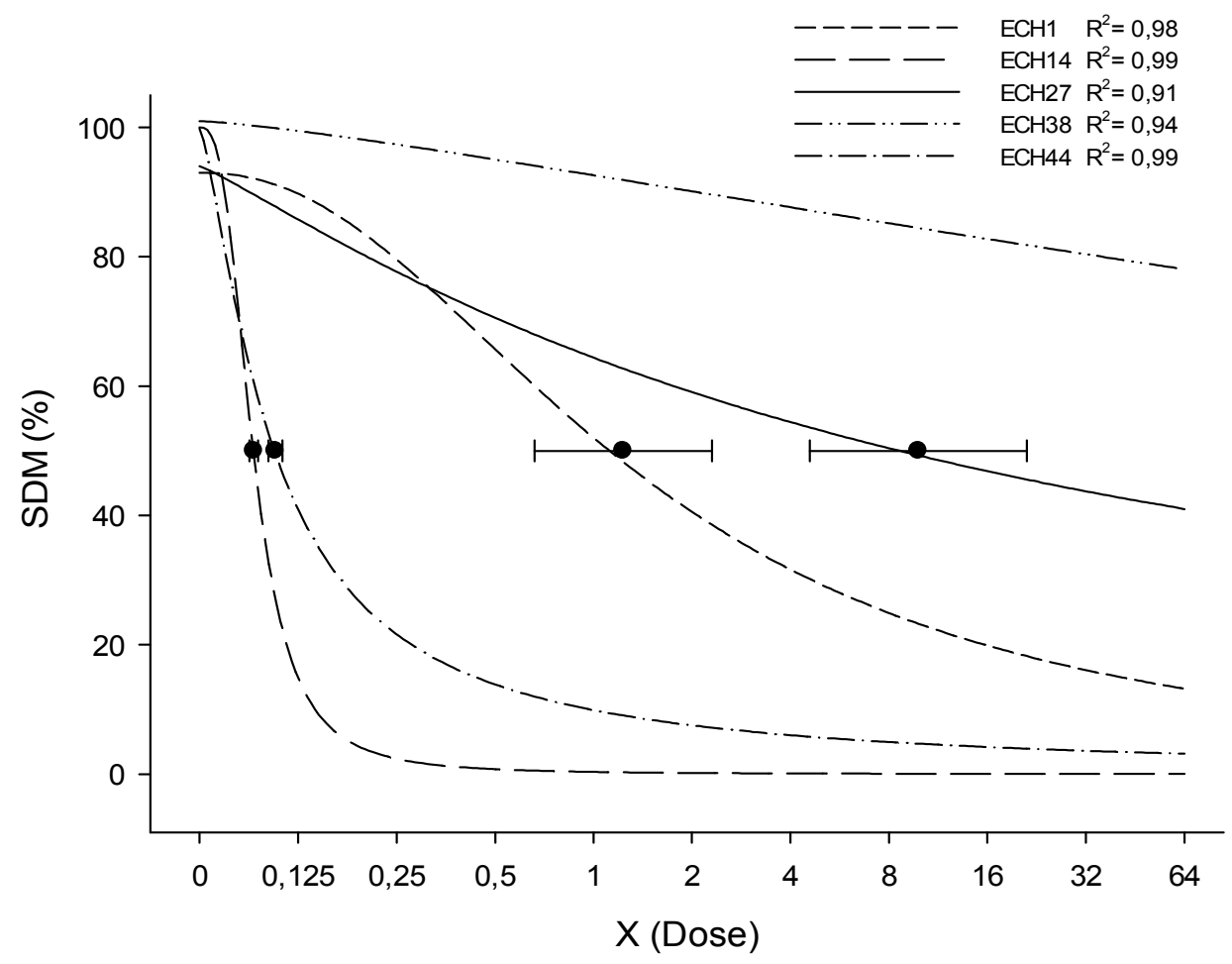

The horizontal bars represent the confidence intervals for the dose causing $50 \%$ control over the plant, with $95 \%$ significance.

Figure 3 - Shoot dry matter (\%) of Echinochloa crusgalli var. mitis (barnyardgrass) accessions that are resistant (ECH1-Pelotas/ Rio Grande do Sul, ECH27-Arroio Grande and ECH38-Rio Grande/Rio Grande do Sul) and susceptible (ECH14-Pelotas/Rio Grande do Sul and ECH44-Rio Grande/Rio Grande do Sul) to the herbicide imazapyr+imazapic, evaluated on day 28 after the application of the treatment. 
The fact that it is impossible to calculate $\mathrm{C}_{50}$ for ECH38 may be explained by the possible genetic variability in the different populations of barnyardgrass, which is affected by several evolutionary factors, such as the interaction between crop and weed, the gene flow through pollen and seed dispersion, the geographic distribution and the natural selection (Huangfu et al., 2009). Thus, the differences observed between $\mathrm{C}_{50}$ and $\mathrm{GR}_{50}$ may be due to genetic characteristics among barnyardgrass accessions, possibly influencing their responses to the herbicide. The genetic constitution of a species may determine varying degrees of herbicide resistance or susceptibility (Hartwing et al., 2008).

It was possible to confirm the resistance of barnyardgrass accessions from areas where the herbicide was the main selection agent. As for the losses caused by the resistance of weeds in a certain area, the population of resistant accession plants is enough to limit the production of agricultural cultures, with the need of changes in the used management practices (Moreira et al., 2010). As for the prevention and management of resistance, the most important aspect is the recommendation of practices and production systems in which the selection pressure of plants resistant to a certain herbicide is reduced (Boerboom, 1999).

\section{Alternative chemical control}

For this study, a significant interaction between the accession and herbicide factors was observed (Tables 2 and 3). The controlling effect of herbicides varied according to the evaluated accession. In the evaluation performed on day 28 DAA (Table 2), all herbicides satisfactorily controlled susceptible accessions. For the resistant accession ECH1, the alternative herbicides cyhalofop-butyl, profoxydim, clethodim, quinclorac, propanil and glyphosate were effective in controlling, whereas the herbicide quinclorac presented only $4 \%$ and $15 \%$ of control for the accessions ECH27 and ECH38, respectively. However, ALS inhibiting herbicides, such as imazethapyr + imazapic, imazapyr + imazapic, bispyribac-sodium and penoxsulam, did not control the other resistant accessions. On the other hand, propanil presented a control level below $70 \%$ for ECH27 and did not differ significantly from the other treatments.

According to studies conducted by Tranel and Wright (2002), ALS inhibiting herbicides have the characteristic of high effectiveness, when used at commercial doses on sensitive biotypes. Even if these herbicides controlled effectively the susceptible accessions ECH14 and EH44, it is importance not depend on a few or exclusively one or more herbicides belonging to a sole mechanism of action to control and manage barnyardgrass in irrigated rice areas, since resistance can occur quickly for herbicides with other target site (Walsh et al., 2006).

In the SDM evaluation performed on day 28 DAA (Table 3), the susceptible accessions ECH14 and ECH44 showed reduction, since all herbicides controlled these accessions. However, for the resistant accessions ECH27 and ECH38, the production of SDM was practically zero for plants submitted to the application of the registered dose of cyhalofop-butyl, profoxydim, clethodim and glyphosate. However, when ALS inhibitors (imazethapyr + imazapic, imazapyr + imazapic, bispyribac-sodium, penoxsulam) and auxin mimics (quinclorac) were used at the maximum registered doses, there was small SDM reduction, suggesting that for these accessions there is a possible cross-resistance with ALS inhibitors and a multiple resistance with auxin mimics. For the resistant accession ECH1, there was a SDM reduction by $24 \%$ for the herbicide imazapyr + imazapic, when compared to the control sample. However, this significant difference did not prevent the development of the plant and the seed production of this accession (data not presented).

Treatments with profoxydim, clethodim, propanil and glyphosate were the most effective, not allowing plants growth thus demonstrating the effectiveness of these herbicides as an alternative control when there is resistance to ALS inhibitors in Echinochloa crusgalli accessions. In this study, the accessions ECH1 and $\mathrm{ECH} 14$, coming from Pelotas, were controlled by cyhalofopbutyl (955 and 90\%, respectively), but in the destructive evaluation on day 28 DAA, there was still dry matter production by the plants.

The results indicate that the application of ALS inhibiting herbicides from three different chemical groups did not satisfactorily control the resistant access ECH1, suggesting that it presents cross resistance, since weeds selected with an ALS inhibitor also presented cross 
Table 2 - Control (\%) of Echinochloa crusgalli var. mitis (barnyardgrass) accessions that are resistant (ECH1-Pelotas/Rio Grande do Sul, ECH27-Arroio Grande and ECH38-Rio Grande/Rio Grande do Sul) and susceptible (ECH14-Pelotas/Rio Grande do Sul and ECH44-Rio Grande/Rio Grande do Sul) to the herbicide imazapyr+imazapic with alternative herbicides, evaluated on day 28 after the application of the treatment (DAA)

\begin{tabular}{|l|c|c|c|c|c|}
\hline \multirow{2}{*}{ Treatment } & \multicolumn{5}{|c|}{$28 \mathrm{DAA}$} \\
\cline { 2 - 6 } & $\begin{array}{c}\text { ECH1 } \\
(\mathrm{R})\end{array}$ & $\begin{array}{c}\text { ECH14 } \\
(\mathrm{S})\end{array}$ & $\begin{array}{c}\text { ECH27 } \\
(\mathrm{R})\end{array}$ & $\begin{array}{c}\text { ECH38 } \\
(\mathrm{R})\end{array}$ & $\begin{array}{c}\text { ECH44 } \\
(\mathrm{S})\end{array}$ \\
\hline Control sample & $0.0 \mathrm{cA}$ & $0.0 \mathrm{cA}$ & $0.0 \mathrm{eA}$ & $0.0 \mathrm{eA}$ & $0.0 \mathrm{Ae}$ \\
\hline Imazethapyr+imazapic & $0.0 \mathrm{cC}$ & $97 \mathrm{aA}$ & $10 \mathrm{~dB}$ & $2.0 \mathrm{eC}$ & $95 \mathrm{bcA}$ \\
\hline Imazapyr+imazapic & $5.0 \mathrm{Bc}$ & $100 \mathrm{aA}$ & $10 \mathrm{~dB}$ & $5.0 \mathrm{eC}$ & $99 \mathrm{abA}$ \\
\hline Bispyribac-sodium & $5.0 \mathrm{bC}$ & $100 \mathrm{aA}$ & $21 \mathrm{cC}$ & $10 \mathrm{cdC}$ & $100 \mathrm{aA}$ \\
\hline Penoxsulam & $0.0 \mathrm{cC}$ & $92 \mathrm{bA}$ & $2.0 \mathrm{eC}$ & $12 \mathrm{bcB}$ & $95 \mathrm{dA}$ \\
\hline Cyhalofop-butyl & $98 \mathrm{aA}$ & $96 \mathrm{aA}$ & $100 \mathrm{aA}$ & $98 \mathrm{aA}$ & $95 \mathrm{cdA}$ \\
\hline Profoxydim & $100 \mathrm{aA}$ & $100 \mathrm{aA}$ & $100 \mathrm{aA}$ & $100 \mathrm{aA}$ & $100 \mathrm{aA}$ \\
\hline Clethodim & $100 \mathrm{aA}$ & $100 \mathrm{aA}$ & $100 \mathrm{aA}$ & $100 \mathrm{aA}$ & $100 \mathrm{aA}$ \\
\hline Quinclorac & $98 \mathrm{aA}$ & $98 \mathrm{aA}$ & $4.0 \mathrm{eC}$ & $15 \mathrm{bB}$ & $98 \mathrm{bcA}$ \\
\hline Propanil & $100 \mathrm{aA}$ & $100 \mathrm{aA}$ & $68 \mathrm{bB}$ & $100 \mathrm{aA}$ & $100 \mathrm{aA}$ \\
\hline Glyphosate & $100 \mathrm{aA}$ & $100 \mathrm{aA}$ & $100 \mathrm{aA}$ & $100 \mathrm{aA}$ & $100 \mathrm{aA}$ \\
\hline- VC $(\%)$ & & & 4.76 & & \\
\hline
\end{tabular}

* Averages followed by the same lowercase letter in the column and the same capital letter on the line do not differ significantly by Duncan's test $(\mathrm{p} \leq 0.05)$.

Table 3 - Shoot dry matter (SDM) (g per plant) on day 28 after the application of treatments on Echinochloa crusgalli var. mitis (barnyardgrass) accessions that are resistant (ECH1-Pelotas/Rio Grande do Sul, ECH27-Arroio Grande and ECH38-Rio Grande/

Rio Grande do Sul) and susceptible (ECH14-Pelotas/Rio Grande do Sul and ECH44-Rio Grande/Rio Grande do Sul) to the herbicide imazapyr+imazapic with alternative herbicides

\begin{tabular}{|l|c|c|c|c|c|}
\hline \multirow{2}{*}{ Treatment } & \multicolumn{5}{|c|}{ SDM } \\
\cline { 2 - 6 } & $\begin{array}{c}\text { ECH1 } \\
(\mathrm{R})\end{array}$ & $\begin{array}{c}\text { ECH14 } \\
(\mathrm{S})\end{array}$ & $\begin{array}{c}\text { ECH27 } \\
(\mathrm{R})\end{array}$ & $\begin{array}{c}\text { ECH38 } \\
(\mathrm{R})\end{array}$ & $\begin{array}{c}\text { ECH44 } \\
(\mathrm{S})\end{array}$ \\
\hline Control sample & $2.28 \mathrm{aB}$ & $2.21 \mathrm{aBC}$ & $2.38 \mathrm{aA}$ & $2.23 \mathrm{aC}$ & $2.15 \mathrm{aC}$ \\
\hline Imazethapyr+imazapic & $2.17 \mathrm{bA}$ & $0.11 \mathrm{bcB}$ & $2.22 \mathrm{cA}$ & $2.21 \mathrm{aA}$ & $0.01 \mathrm{cC}$ \\
\hline Imazapyr+imazapic & $2.12 \mathrm{bA}$ & $0.08 \mathrm{cB}$ & $2.16 \mathrm{cA}$ & $2.18 \mathrm{aA}$ & $0.0 \mathrm{cC}$ \\
\hline Bispyribac-sodium & $2.31 \mathrm{aA}$ & $0.12 \mathrm{bcC}$ & $2.24 \mathrm{cB}$ & $2.17 \mathrm{aB}$ & $0.01 \mathrm{cD}$ \\
\hline Penoxsulam & $2.02 \mathrm{cC}$ & $0.15 \mathrm{bD}$ & $2.36 \mathrm{bA}$ & $2.15 \mathrm{aB}$ & $0.02 \mathrm{bE}$ \\
\hline Cyhalofop-butyl & $0.11 \mathrm{bA}$ & $0.13 \mathrm{bA}$ & $0.0 \mathrm{cC}$ & $0.0 \mathrm{cC}$ & $0.05 \mathrm{bB}$ \\
\hline Profoxydim & $0.03 \mathrm{eA}$ & $0.04 \mathrm{dA}$ & $0.0 \mathrm{eB}$ & $0.0 \mathrm{cB}$ & $0.0 \mathrm{cB}$ \\
\hline Clethodim & $0.01 \mathrm{eB}$ & $0.04 \mathrm{dA}$ & $0.0 \mathrm{eB}$ & $0.0 \mathrm{cB}$ & $0.0 \mathrm{cB}$ \\
\hline Quinclorac & $0.03 \mathrm{eC}$ & $0.11 \mathrm{bcC}$ & $2.45 \mathrm{aA}$ & $1.77 \mathrm{bB}$ & $0.04 \mathrm{bC}$ \\
\hline Propanil & $0.01 \mathrm{eC}$ & $0.09 \mathrm{cB}$ & $0.79 \mathrm{dA}$ & $0.0 \mathrm{cC}$ & $0.0 \mathrm{cC}$ \\
\hline Glyphosate & $0.01 \mathrm{eB}$ & $0.11 \mathrm{bcA}$ & $0.01 \mathrm{eB}$ & $0.0 \mathrm{cB}$ & $0.0 \mathrm{cB}$ \\
\hline- VC $(\%)$ & & & 12.1 & & \\
\hline
\end{tabular}

* Averages followed by the same lowercase letter in the column and the same capital letter on the line do not differ significantly by Duncan's test $(\mathrm{p} \leq 0.05)$.

resistance to other compounds with activity from the same enzyme (Primiani et al., 1990; Ribas and Merotto, 1999). Most studies report that herbicide-resistant biotypes from the imidazolinone group, with a mutation at the site of action of the herbicide in the ALS enzyme, demonstrate varying levels of cross-resistance for the chemical groups sulfonylureas and triazolopyrimidines (Walsh et al., 2004). Variations in the cross-resistance level within ALS inhibitors may be possibly due to the differentiated and particular binding of each herbicide to the site of action and the different mutations occurring in the gene encoding the ALS enzyme (Powles and Preston, 2013). 
In the case of the ECH27 and ECH38 accessions, the quinclorac treatment was also not effective, since both produced large amounts of SDM. Barnyardgrass resistant to quinclorac were also found in rice fields in Southern Brazil (Andres et al., 2007); since then, cases involving the resistance to this herbicide has increased. For weeds showing resistance to more than one action mechanism, the management in irrigated rice fields becomes more complex, since the herbicide options for chemical control decrease.

Herbicides with alternative mechanism of action then ALS inhibitors, such as ACCase inhibitors (cyhalofop-butyl, profoxydim and clethodim), glyphosate and propanil, are effective and can be used to control imazapyr + imazapic resistant barnyardgrass accessions. However, other ALS inhibiting herbicides, as well as the auxin mimic (quinclorac), are not effective in controlling.

Accessions of Echinochloa crusgallivar mitis on rice fields in Rio Grande do Sul show resistance to ALS inhibiting herbicides, thus making the correct use of technology necessary, not consecutively cultivating rice in the same areas, as well as adopting a good planning of the herbicides to be used, rotating action mechanisms and avoiding to accelerate the evolution of resistance.

\section{ACKNOWLEDGMENTS}

To the Conselho de Aperfeiçoamento de Pessoal do Nivel Superior (CAPES) for granting the scholarship (PPGFs/UFPel) to the first author. To Professor Raquel Lüdke from Departamento de Botânica - Universidade Federal de Pelotas - UFPel for identifying Echinochloa crusgalli var. mitis accessions.

\section{REFERENCES}

Andres A. et al. Detecção da resistência de capim-arroz (Echinochloa sp.) ao herbicida quinclorac em regiões orizícolas do sul do Brasil. Planta Daninha. 2007;25(1):221-6.

Boerboom C.M. Nonchemical options for delaying weed resistance to herbicides in Midwest cropping systems. Weed Technol. 1999;13(3):636-42.

Christoffoleti P.J. Curvas de dose-resposta de biótipos resistente e suscetível de Bidens pilosa L. aos herbicidas inibidores da ALS Sci Agric. 2002;59(3):513-9.

Cechin J. et al. Resistence of radish biotypes to iodosulfuron and alternative control. Planta Daninha. 2016;34(1):151-60.

Duggleby R.G. et al. Structure and mechanism of inhibition of plant acetohydroxyacid synthase. Plant Physiol Biochem. 2008;46(3):309-24.

Frans R, Crowley H. Experimental design and techniques for measuring and analyzing plant responses to weed control practices. In: Camper N.D., editor. Research methods in weed science. $3^{\text {rd }}$.ed. Champaign: Southern Weed Science Society, 1986.

Gazziero, D.L.P. et al. Critérios para relatos oficiais estatísticos de biótipos de plantas daninhas resistentes a herbicidas. In: Agostinetto, D., Vargas, L., editores. Resistência de plantas daninhas a herbicidas no Brasil. Passo Fundo: Berthier, 2009. p.91-101.

Han H. et al. A novel amino acid substitution Ala-122-Tyr in ALS comfers high-level and broad resistance across ALS-inhibiting herbicides. Pest Manage Sci. 2012;68(3):1164-70.

Hartwing I. et al. Tolerância de trigo (Triticum aestivum) e aveia (Avena sp.) a herbicidas inibidores da enzima acetolactato sintase (ALS). Planta Daninha. 2008;26(2):361-8.

Heap I. The international survey of herbicide resistant weeds. [accessed on: 10 Jul. 2017]. Available at: http:// www.weedscience.org.

Huangfu C. et al. Morphological disparities in the epidermal and anatomical features of the leaf among wild Brassica juncea populations. Weed Biol Manage. 2009;9(3):234-42. 
Moreira M.S. et al. Herbicidas alternativos para controle de biótipos de Conyza bonariensis e C. canadensis resistentes ao glyphosate. Planta Daninha. 2010;28(1):167-75.

Moura D. et al. Multiple resistance of Sagittaria montevidensis biotypes to acetolactate synthase and photosystem II inhibiting herbicides. Planta Daninha. 2015;33(4):779-86.

Oliveira Neto M. et al. Estratégias de manejo de inverno e verão visando ao controle de Conyza bonariensis e Bidens pilosa. Planta Daninha. 2010;28(4):1107-16.

Perez-Jones A. Investigating the mechanisms of glyphosate resistance in Lolium multiflorum. Planta. 2007;226(2):395-404.

Powles S.B., Preston C. Herbicide cross resistance and multiple resistance in plants. [accessed on: 2016 Nov. 16] Available at: http://www.hracglobal.com/Publications/HerbicideCrossResistanceandMultipleResistance.aspx.

Powles S.B., Yu Q. Evolution in action: plants resistant to herbicides. Ann Rev Plant Biol. 2010;61(7):317-47.

Primiani M.M. et al. Resistance of Kochia (Kochia scoparia) to sulfonylurea and imidazolinone herbicides. Weed Technol. 1990;4:169-72.

Ribas A., Merotto A. Resistência de amendoim-bravo aos herbicidas inibidores da enzima acetolactato sintase. Planta Daninha. 1999;17(3):367-73.

Seefeldt S.S. et al. Log-logistic analysis of herbicide dose-response relationships. Weed Technol. 1995;9(2):218-27.

Sigmaplot - Scientific Graphing Software. Version 12.0. 2012.

Sociedade Sul-Brasileira de Arroz Irrigado - SOSBAI. Arroz irrigado: recomendações técnicas da pesquisa para o Sul do Brasil. Gravatal: 2012. 188p.

Tranel P.J., Wright T.R. Resistence of weeds to ALS-inhibiting herbicides: what have we learned? Weed Sci. 2002;50(6):700-12.

Walsh M.J. et al. Frequency, distribution and mechanisms of herbicide resistance in Western Australian wild radish (Raphanus raphanistrum L.) populations: a review; In: Conference paper of the 15th Australian Weeds Conference. Adelaide: 2006. p.484-7.

Walsh M.J. et al. Multiple-herbicide resistance across four modes of action in wild radish (Raphanus raphanistrum). Weed Sci. 2004;52(1):8-13. 